\title{
Effect of Periodontal Treatment on Preterm Birth Rate: Meta-analysis
}

\begin{abstract}
Introduction: During pregnancy, the prevalence and severity of gingivitis have been reported to be elevated. Studies suggest that periodontitis is associated with an increased risk of preterm birth (PTB), as well as low birth weight (LBW) and pre-eclampsia. The purpose of this meta-analysis is to determine whether the treatment of periodontal disease by mechanical debridement and oral hygiene instructions during pregnancy will reduce the incidence of PTB $<37$ weeks.
\end{abstract}

Materials and methods: Literature search was conducted for all clinical trials that related to periodontal disease and PTB from 2005 to 2012. Five were selected based no randomization technique, sample size and treatment approach. There were 2,767 patients randomly assigned to treatment group, in these trials, and 2,592 subjects randomly assigned to control group.

Results: There were 276 (9.98\%) PTBs in treatment group vs $270(10.42 \%)$ in control group. A total of $216(8 \%)$ LBW were seen in experimental groups and $193(7.5 \%)$ in control group. Our results showed no significant difference in the incidence of PTB with or without received periodontal treatment during pregnancy. Risk ratio $(\mathrm{RR})$ was $0.99(95 \% \mathrm{Cl}$ : 0.74-1.33) $(\mathrm{p}$ $=0.97)$ with moderate heterogeneity 12.33. $\mathrm{df}=4(\mathrm{p}=0.02)$ with $\mathrm{I} 2=68 \%$. Experimental groups showed better periodontal health after delivery.

Conclusion: Periodontal treatment may improve the oral health during pregnancy without affecting the pregnancy outcome however; it did not reduce the incidence of PTB and LBW. Larger meta-analysis with less heterogeneity is needed.

Keywords: Periodontal disease, Pregnancy, Low birth weight, Preterm birth, Meta-analysis.

How to cite this article: Alobaid AS. Effect of Periodontal Treatment on Preterm Birth Rate: Meta-analysis. World J Dent 2013;4(4):256-261

Source of support: Nil

Conflict of interest: None declared

\section{INTRODUCTION}

Preterm birth (PTB, which remains a major public health issue in the United States) accounts for substantial morbidity and death. Unfortunately, the incidence of PTB has been largely unchanged in recent years, hovering at $12 \%{ }^{1}$ About half of mothers delivering preterm infants have no known risk factors. ${ }^{2}$ There is substantial observational evidence from a variety of populations that links maternal periodontal disease to PTB, possibly because of the maternal inflammatory response to periodontal disease..$^{3-7}$

Destructive periodontal disease (periodontitis) is common, with a reported prevalence of $30 \%$ in some populations. ${ }^{8}$ Plaque-induced gingivitis is an inflammation of the gingiva resulting from bacterial infection, and this disease is the most common periodontal disease in pregnant women. ${ }^{9}$ During pregnancy, the prevalence and severity of gingivitis have been reported to be elevated yet unrelated to the amount of plaque present. ${ }^{11,12}$ However, the severity of gingivitis is correlated with sex steroid hormone levels during pregnancy. ${ }^{13}$

One of the hypotheses to explain the relation between periodontal disease and PTB is that periodontal infection is a source of bacteria and bacterial products that may spread from the infected peridontium to the amniotic cavity, as when transient bacteremia occurs in patients with periodontitis. ${ }^{6,14,17,18}$ It has been demonstrated that transient bacteremia commonly occurs in subjects with periodontitis ${ }^{19}$ as well as in those with gingival inflammation, ${ }^{20}$ and bacteria or their products may conceivably reach the placental tissue providing the inflammatory effect for labor induction. ${ }^{9}$ Recent studies suggest that periodontitis, an inflammatory disease caused primarily by Gram-negative bacteria that destroy tooth supporting connective tissue and bone, is associated with an increased risk of PTB, as well as low birth weight (LBW) and pre-eclampsia. ${ }^{7,21}$

Studies have suggested that maternal periodontal disease is associated with an increased risk for preterm delivery. ${ }^{2,22-30}$ Many case series and cohort studies have shown significant associations between periodontal disease and PTB, ${ }^{6}$ fetal growth restriction ${ }^{31}$ and pre-eclampsia. ${ }^{21}$ The mechanisms by which an inflamed and infected periodontium could adversely affect the pregnant uterus and developing fetus are uncertain, although evidence suggests roles for translocation of periodontopathic organisms, and stimulation and release of inflammatory mediators and prostaglandins into the maternal circulation. ${ }^{9}$

Results from four randomized, single-center clinical trials suggest that periodontal treatment during pregnancy may reduce PTBs. ${ }^{15-17,32,33}$ However, results of a randomized, multicenter clinical trial show no difference between treatment and control groups for mean gestational age and for PTB at less than 37 weeks. ${ }^{34}$ A recent meta-analysis of 17 observational studies indicated the association between periodontal disease and PTB or LBW infants. ${ }^{35}$

The purpose of this meta-analysis is to determine whether the treatment of periodontal disease by mechanical debridement and oral hygiene instructions during pregnancy 
will reduce the incidence of $\mathrm{PTB}<37$ weeks. This is a metaanalysis of the largest, based on sample size; up to date five randomized controlled clinical trials.

\section{MATERIALS AND METHODS}

\section{Identification of Randomized Trials}

One independent investigator (AA) searched the clinical trials website, Medline, Google scholars, and PubMed with English language, clinical trials and 2005 up restrictions. We used the following researching algorithms (periodontal therapy, treatment, diseases, periodontitis or gingivitis) and (PTB, preterm labor, LBW or PTB $<37$ weeks).

\section{Eligibility Criteria}

At the very beginning of the searching method we decided to select the best five randomized control trials based on the sample size effect and the strength of the study methodology. We selected all studies that compare periodontal therapy including mechanical removal of plaque and calculus (scaling and root planning) vs no treatment placebo or prophylaxis and OHI. The study also included if it included pregnant women with periodontal problem. ${ }^{10}$ All single armed, nonrandomized, pure observational studies were excluded. Also, all studies accepting subjects with antibiotic use were excluded.

The electronic search found 353 articles talk about periodontal disease and PTB, 343 at Medline and 10 at clinical trials. After limiting the research to randomized clinical trials we found 46 articles of all kinds. In addition, after more specific research selection we end up with 12 articles. All 12 clinical trials that we found from these searching methods were retrieved from NYU College of Dentistry Library at VA Hospital and examined for eligibility criteria. After going through all these articles we considered two were ineligible and 10 were recorded as eligible trials. We selected the most up to date articles with the largest sample size and best methodology. We finally end up with five items to be in our meta-analysis.

\section{Data Extraction}

Data were extracted by (AA) from all five eligible trials. Multiple factors were taken in consideration like author's name, journal's name, publication year, gestational age at enrollment, and number of subjects in the trial and in each arm. Furthermore, baseline characteristic that can affect the PTB were taken in consideration like mean age of the subjects, smoking history, history of PTB (Table 1). Periodontal status was checked at baseline by determining the probing depth and bleeding with probing (Table 2). Birth related events were recorded at baseline for each subject in both arms of all studies: stillbirth, spontaneous abortion, number of PTB ( $<37$ weeks), LBW infants $(<2,500 \mathrm{gm})$ in (Table 3).

\section{STATISTICAL ANALYSIS}

The risk ratio (RR) was calculated for each study to estimate the relative risk of abortion/stillbirth, PTB, and LBW infants

\begin{tabular}{|c|c|c|c|c|c|c|c|c|c|c|}
\hline$I D$ & Study & $T x$ & $\begin{array}{l}\text { Total } \\
\text { patient } \\
\text { number }\end{array}$ & $\begin{array}{l}\text { Patient } \\
\text { followed } \\
\text { up }\end{array}$ & $\begin{array}{l}\text { Live } \\
\text { birth }\end{array}$ & $\begin{array}{l}\text { Gestation } \\
\text { age (wks) }\end{array}$ & $\begin{array}{l}\text { Age } \\
\text { mean } \\
(Y)\end{array}$ & $\begin{array}{l}\text { Previous } \\
\text { PTB/ } \\
\text { LBW } \\
(\%)\end{array}$ & $\begin{array}{l}<12 \\
\text { Education } \\
(\%)\end{array}$ & $\begin{array}{l}\text { Smoke } \\
(\%)\end{array}$ \\
\hline \multirow[t]{2}{*}{1} & $\begin{array}{l}\text { Lopez et al }{ }^{38} \\
2005\end{array}$ & Yes & 580 & 570 & 563 & $<22$ & 25.54 & 3.44 & 77.76 & 14.47 \\
\hline & & No & 290 & 286 & 282 & & 24.98 & 7.47 & 80.78 & 17.44 \\
\hline \multirow[t]{2}{*}{2} & $\begin{array}{l}\text { Michalowicz } \\
\text { et } \mathrm{al}^{34}\end{array}$ & Yes & 413 & 407 & 402 & $<21$ & 26.1 & 12.5 & 76.3 & 13 \\
\hline & 2006 & No & 410 & 405 & 391 & & 25.9 & 16.5 & 77.6 & 13 \\
\hline \multirow[t]{2}{*}{3} & $\begin{array}{l}\text { Offenbacher } \\
\text { et } \text { al }^{36}\end{array}$ & Yes & 903 & 880 & 871 & $<23$ & 25.4 & 10.6 & 75.4 & NA \\
\hline & 2009 & No & 903 & 881 & 874 & & 25.3 & 9.0 & 76.5 & NA \\
\hline \multirow[t]{2}{*}{4} & $\begin{array}{l}\text { Newnham } \\
\text { et } \mathrm{al}^{37}\end{array}$ & Yes & 546 & 538 & 538 & $<20$ & 30.5 & 13.2 & 48.2 & 17.7 \\
\hline & 2009 & No & 541 & 540 & 535 & & 30.5 & 11.1 & 53.7 & 17.7 \\
\hline \multirow[t]{2}{*}{5} & $\begin{array}{l}\text { Macones } \\
\text { et } \mathrm{al}^{8}\end{array}$ & Yes & 376 & 359 & 351 & $<20$ & 24.1 & 11.7 & 71.5 & NA \\
\hline & 2010 & No & 380 & 361 & 352 & & 24.4 & 12.9 & 64.7 & NA \\
\hline
\end{tabular}

Tx: Treatment; PTB: Preterm birth; LBW: Low birth weight; Smoke: Smoking status 


\begin{tabular}{|c|c|c|c|c|c|c|c|}
\hline$I D$ & Study & $T x$ & $\begin{array}{l}\text { Disease } \\
\text { type }\end{array}$ & $\begin{array}{l}\text { Definition of } \\
\text { periodontal } \\
\text { disease }\end{array}$ & $\begin{array}{l}\text { Natural } \\
\text { teeth }(N)\end{array}$ & $\begin{array}{l}B O P \\
\text { (\%) }\end{array}$ & $\begin{array}{l}P D>4 \mathrm{~mm} \\
(\%)\end{array}$ \\
\hline \multirow[t]{2}{*}{1} & \multirow[t]{2}{*}{$\begin{array}{l}\text { Lopez et al }{ }^{38} \\
2005\end{array}$} & Yes & \multirow[t]{2}{*}{ Gingivitis } & \multirow[t]{2}{*}{$\begin{array}{l}\text { BOP }>25 \% \text { of } \\
\text { sites with CAL } \\
>2 \mathrm{~mm}\end{array}$} & 25 & 55.09 & 9.24 \\
\hline & & No & & & 24.8 & 51.42 & 12.23 \\
\hline \multirow[t]{2}{*}{2} & \multirow{2}{*}{$\begin{array}{l}\text { Michalowicz } \\
\text { et al }^{34} \\
2006\end{array}$} & Yes & \multirow[t]{2}{*}{$\begin{array}{l}\text { Mild- } \\
\text { moderate }\end{array}$} & $\begin{array}{l}>4 \text { teeth with } \\
\mathrm{CAL}>2 \mathrm{~mm}\end{array}$ & 26.7 & 69.6 & 26.5 \\
\hline & & No & & $\begin{array}{l}\mathrm{BOP}>35 \% \\
\mathrm{PD}>4 \mathrm{~mm}\end{array}$ & 26.8 & 69.0 & 24.8 \\
\hline \multirow[t]{2}{*}{3} & Offenbacher & Yes & \multirow{2}{*}{$\begin{array}{l}\text { Not } \\
\text { specified }\end{array}$} & \multirow{2}{*}{$\begin{array}{l}>3 \text { teeth with } \\
\mathrm{CAL}>3 \mathrm{~mm}\end{array}$} & $>20$ & 45.2 & 26.1 \\
\hline & $\begin{array}{l}\text { et al } \\
2009\end{array}$ & No & & & $>20$ & 47.1 & 26.6 \\
\hline \multirow[t]{2}{*}{4} & $\begin{array}{l}\text { Newnham } \\
\text { et } \mathrm{al}^{37}\end{array}$ & & \multirow[t]{2}{*}{$\begin{array}{l}\text { Moderate- } \\
\text { severe }\end{array}$} & \multirow[t]{2}{*}{$\begin{array}{l}\mathrm{PD}>4 \mathrm{~mm} \text { at } \\
12 \text { sites }\end{array}$} & 28.8 & 71.29 & 14.8 \\
\hline & 2009 & No & & & 28.7 & 77.7 & 14.9 \\
\hline \multirow[t]{2}{*}{5} & $\begin{array}{l}\text { Macones } \\
\text { et al }{ }^{8}\end{array}$ & Yes & \multirow[t]{2}{*}{$\begin{array}{l}\text { Moderate- } \\
\text { severe }\end{array}$} & \multirow[t]{2}{*}{$\begin{array}{l}>3 \text { teeth with } \\
\mathrm{CAL}>3 \mathrm{~mm}\end{array}$} & NA & NA & NA \\
\hline & 2010 & No & & & NA & NA & NA \\
\hline
\end{tabular}

Tx: Treatment; BOP: Bleeding on probing; PD: Probing depth

Table 3: Pregnancy and periodontal-related parameters after treatment

\begin{tabular}{|c|c|c|c|c|c|c|c|}
\hline ID & Study & $T x$ & $\begin{array}{l}\text { PTB } \\
\text { (N) }\end{array}$ & $\begin{array}{l}\text { Stillbirth } \\
\text { abortion } \\
\text { (N) }\end{array}$ & $\begin{array}{l}\angle B W \\
(N)\end{array}$ & $\begin{array}{l}\text { BOP } \\
(\%)\end{array}$ & $\begin{array}{l}P D>4 \\
m m(\%)\end{array}$ \\
\hline \multirow[t]{2}{*}{1} & \multirow{2}{*}{ 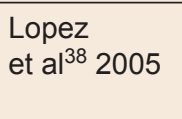 } & Yes & 18 & 7 & 4 & 15.09 & 1.8 \\
\hline & & No & 17 & 4 & 3 & 56.6 & 14.5 \\
\hline \multirow[t]{2}{*}{2} & \multirow{2}{*}{$\begin{array}{l}\text { Michalowicz } \\
\text { et al }{ }^{34} 2006\end{array}$} & Yes & 44 & 5 & 40 & 3.8 & NA \\
\hline & & No & 38 & 14 & 43 & 22.7 & NA \\
\hline \multirow[t]{2}{*}{3} & \multirow{2}{*}{$\begin{array}{l}\text { Offenbacher } \\
\text { et al }{ }^{36} 2009\end{array}$} & Yes & 104 & NA & 71 & 17.7 & 13.2 \\
\hline & & No & 118 & NA & 72 & 12.2 & 9.3 \\
\hline \multirow[t]{2}{*}{4} & \multirow[t]{2}{*}{$\begin{array}{l}\text { Newnham } \\
\text { et al }{ }^{37} 2009\end{array}$} & Yes & 52 & 0 & 52 & 28.7 & 3.3 \\
\hline & & No & 50 & 4 & 39 & 70.2 & 13.8 \\
\hline \multirow[t]{2}{*}{5} & \multirow{2}{*}{$\begin{array}{l}\text { Macones } \\
\text { et }\left.\right|^{8}{ }^{8} 2010\end{array}$} & Yes & 58 & 8 & 49 & NA & NA \\
\hline & & No & 47 & 9 & 36 & NA & NA \\
\hline
\end{tabular}

Tx: Treatment; PTB: Preterm birth; LBW: Low birth weight; BOP: Bleeding on probing; PD: Probing depth

among treatment group compared with control group. Analysis of abortion, stillbirth, PTB and LBW were based on all randomized subjects except for those who lost the follow-up. Statistical significant was defined as $\mathrm{p}<0.05$.

The $\chi^{2}$ statistical test was used to test the homogeneity of the estimates of RR between studies. Analysis was performed to explain the possible source of heterogeneity between studies on the bases of some baseline characteristics of the trials regarding potential risk factors for PTB and LBW infants.

Previous history of PTB andLBW was taken in consideration. We also, considered the level of education ( $<12$ years) effects on the studies' population. We considered the severity of periodontal disease before randomization in each study and its effect and progression during the course of pregnancy. The data were analyzed using review manager 5 software. 


\section{RESULTS}

\section{Design and Quality of Characteristics}

Lopez et a ${ }^{38}$ trial in 2005 was 2:1 ratio in favor of experimental group; however all other four trials ${ }^{8,34,36,37}$ were in adequate random mode. All studies' primary outcome was the PTB incidence. Two studies ${ }^{8,37}$ estimated $<35$ weeks gestation as primary end point however three studies $^{34,36,38}$ estimated $<37$ weeks.

\section{Outcome Measures}

There were 2,767 patients randomly assigned to treatment group in these trials. On the other hand, there were 2,592 subjects randomly assigned to control group as in (Table 1). We found reported PTB in all trials in both groups except for treatment group of Newham et al, ${ }^{37} 2010$. Cumulatively, there were 276 (9.98\%) observed PTB in women received periodontal treatment during pregnancy. Three studies ${ }^{8,34,36}$ were multicenter studies whereas two studies ${ }^{37,38}$ were single center studies. On the other side, we cumulatively observed that 270 (10.42\%) PTBs in women did not receive periodontal treatment during pregnancy. The number of PTBs was higher in treatment groups in four studies. ${ }^{8,34,37,38}$ The reason for Lopez et al study ${ }^{38}$ was because the randomization ratio of groups was 2:1 favoring treatment group. The number of PTB event was higher in control group in Offenbacher et al study. ${ }^{36}$ Only Lopez et al study ${ }^{38}$ showed statistically significant difference between groups favoring the treatment group whereas all other four ${ }^{8,34,36,37}$ showed no difference regardless single or multicenter type. Metaanalysis regarding PTB incidence revealed no significant difference between compared groups. RR was 0.99 (95\% CI:

\begin{tabular}{|c|c|c|c|c|c|c|}
\hline ID & Study & $T x$ & Event & Total & $\begin{array}{l}\text { Weight } \\
\text { (\%) }\end{array}$ & $\begin{array}{l}\text { Risk ratio } \\
\mathrm{M}-\mathrm{H} \text { random } \\
\mathrm{Cl}(95 \%)\end{array}$ \\
\hline \multirow[t]{2}{*}{1} & $\begin{array}{l}\text { Lopez } \\
\text { et } \mathrm{al}^{38}\end{array}$ & Yes & 12 & 560 & 11.1 & $0.32(0.16-0.65)$ \\
\hline & 2005 & No & 19 & 283 & & \\
\hline \multirow[t]{2}{*}{2} & 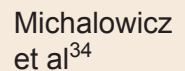 & Yes & 58 & 359 & 21.4 & $1.24(0.87-1.77)$ \\
\hline & 2006 & No & 47 & 361 & & \\
\hline \multirow[t]{2}{*}{3} & $\begin{array}{l}\text { Offenbacher } \\
\text { et } \mathrm{al}^{36}\end{array}$ & Yes & 118 & 903 & 25.6 & $1.13(0.89-1.45)$ \\
\hline & 2009 & No & 104 & 903 & & \\
\hline \multirow[t]{2}{*}{4} & 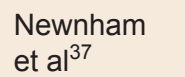 & Yes & 52 & 538 & 20.9 & $1.04(0.72-1.51)$ \\
\hline & 2009 & No & 50 & 540 & & \\
\hline \multirow[t]{2}{*}{5} & 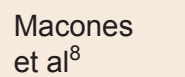 & Yes & 49 & 407 & 21.0 & $1.17(0.81-1.89)$ \\
\hline & 2010 & No & 52 & 405 & & \\
\hline
\end{tabular}

Heterogeneity: 0.07; Chi: 12.33; df: 4; p: 0.02; I: 68; Total for overall effect $(Z): 0.04(p=0.97)$

Study or subgroup
Lopez 2005
Newnham 2009
Offenbacher 2009
Macones 2010
Michalowicz 2006
Total $(95 \% \mathrm{Cl})$
Total events
Heterogeneity. Tau ${ }^{2}=0.07 ; x^{2}=12.33, \mathrm{df}=4(p=0.02) ; 1^{2}=68 \%$
Test for overall effect: $Z=0.04(p=0.97)$

Risk ratio

$\mathrm{M}-\mathrm{H}$, random, $95 \% \mathrm{Cl}$

Graph 1: Forest plot

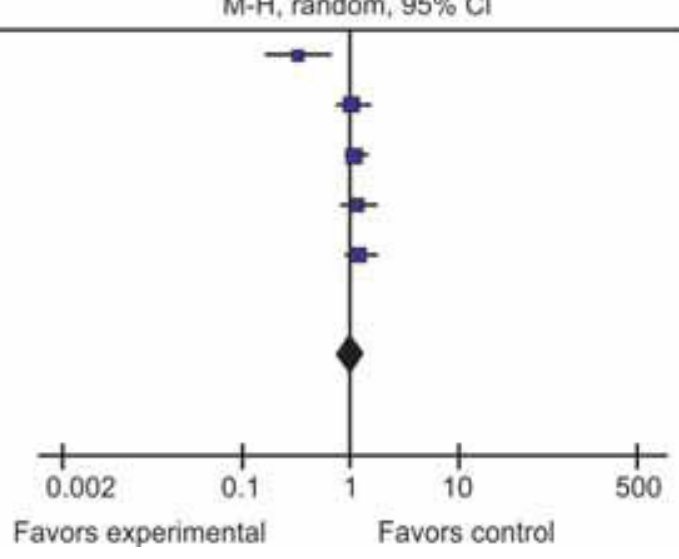




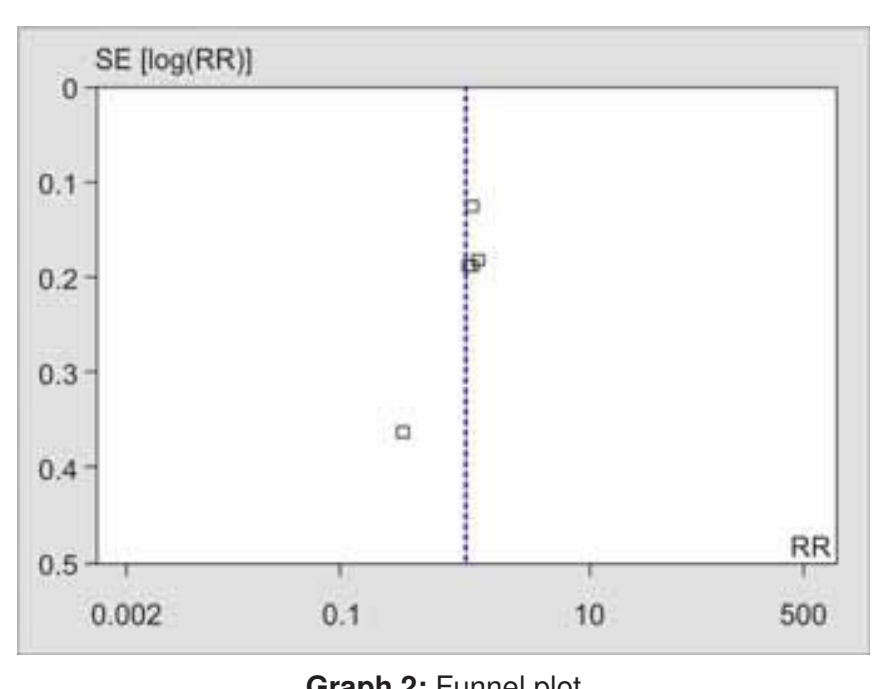

Graph 2: Funnel plot

0.74-1.33) $(\mathrm{p}=0.97)$ with moderate heterogeneity $12.33 . \mathrm{df}=$ $4(\mathrm{P}=0.02) \mathrm{I}^{2}$ (variation in RR attributable to heterogeneity) $=68 \%$ (Table 4). It suggested that periodontal treatment, including scaling and root planning; during pregnancy did not reduce the incidence of PTB among pregnant women diagnosed with periodontal disease.

Forest plot showed the distribution of the selected studies and compared them together based on RR effect with left side favoring the experimental group (Graph 1). It showed no significant difference for total events weight. In addition, (Graph 2) funnel plot showed the distribution of all studies around the RR point with no significant difference.

LBW infants were reported in all five trials. A total of $216(8.0 \%) \mathrm{LBW}$ infants were observed in periodontal treatment group. On the other hand, a total of 193 (7.5\%) were seen in control groups. Studies ${ }^{34,36}$ showed less LBW in control group when compared with other studies. ${ }^{8,37,38}$ Regarding abortions and stillbirths, Offenbranch et al study $^{36}$ did not mention anything about it. However, all other four studies ${ }^{8,34,37,38}$ had a total of $20(1.1 \%)$ stillbirths in experimental groups and $31(1.8 \%)$ stillbirths in control groups.

All studies, regarding periodontal treatment, showed a significant improvement in periodontal condition in treatment groups after delivery except for two. Offenbacher et al study ${ }^{36}$ showed no difference. However, it showed slight improvement in control group whereas Macones et al study ${ }^{8}$ did not mention anything about periodontal probing depth and bleeding index.

\section{DISCUSSION}

Our findings came along with several meta-analyses and randomized clinical trials. It showed no statistically significant difference whether or not we performed periodontal treatment including routine scaling and root planning during pregnancy regarding the final results of pregnancy including PTB, LBW infants and abortion and stillbirths despite the rate of heterogeneity between studies.

The presence or absence of high risk factors is the most important in all studies. We considered previous history of PTB or LBW infants, level of education and smoking status of the mother during pregnancy as the most relevant risk factors in the study. These factors were related to the outcome of delivery more than the periodontal condition. After controlling these factors by randomization we found no significant effect of periodontal condition therefore, the hypothesis of relating periodontal infections to PTB and LBW seemed to be nonvalid.

History of previous PTB or LBW infants is strongly associated with a subsequent PTB. ${ }^{39}$ Thus, the potential of experiencing a second PTB in this subgroup of women is higher than for general population and may be irrelevant from coexisting conditions, such as periodontal disease or smoking. ${ }^{40}$

Lopez et al ${ }^{38}$ was different than other studies in this analysis. All subjects in Lopez et a ${ }^{38}$ were restricted to gingivitis cases only however; other studies selected more advanced periodontal disease, which may be more valid. Also, Lopez et al ${ }^{38}$ randomization was based on 2:1 ratio favoring experimental group. That added to moderate heterogeneity between studies and difficult compression and interpretation of the results.

\section{CONCLUSION}

Since, the periodontal treatment did not influence the outcome of pregnancy regarding PTB and LBW infants and improved the postdelivery periodontal condition; it may be advisable to perform routine scaling and root planning for pregnant woman with no history of PTB. More studies are needed to insure accurate analysis.

\section{REFERENCES}

1. Goldenberg RL, Culhane JF, Iams JD, Romero R. Epidemiology and causes of preterm birth. Lancet 2008;371:75-84.

2. Martin JA, Hamilton BE, Sutton PD, Ventura SJ, Menacker F, Kirmeyer S, et al. Births: final data for 2005. Natl Vital Stat Rep 2007;56:1-103.

3. Jeffcoat MK, Geurs NC, Reddy MS, Goldenberg RL, Hauth JC. Current evidence regarding periodontal disease as a risk factor in preterm birth. Ann Periodontol 2001;6:183-188.

4. Goepfert AR, Jeffcoat MK, Andrews WW, Faye-Petersen O, Cliver SP, Goldenberg RL, Hauth JC. Periodontal disease and upper genital tract inflammation in early spontaneous preterm birth. Obstet Gynecol 2004;104:777-783.

5. Jeffcoat MK, Geurs NC, Reddy MS, Cliver SP, Goldenberg RL, Hauth JC. Periodontal infection and preterm birth: results of a prospective study. J Am Dent Assoc 2001;132:875-880.

6. Offenbacher S, Katz V, Fertik G, Collins J, Boyd D, Maynor G, McKaig R, Beck J. Periodontal infection as a possible risk factor for preterm low birth weight. J Periodontol 1996;67 (10 Suppl):1103-1113. 
7. Offenbacher S, Boggess KA, Murtha AP, Jared HL, Lieff S, McKaig RG, Mauriello SM, Moss KL, Beck JD. Progressive periodontal disease and risk of very preterm delivery. Obstet Gynecol 2006;107:29-36.

8. Macones GA, Parry S, Nelson DB, Strauss JF, Ludmir J, Cohen AW, et al. Treatment of localized periodontal disease in pregnancy does not reduce the occurrence of preterm birth: results from the Periodontal Infections and Prematurity Study (PIPS). Am J Obstet Gynecol 2010;202:147.e1-8.

9. Offenbacher S, Jared HL, O'Reilly PG, Wells SR, Salvi GE, Lawrence HP, et al. Potential pathogenic mechanisms of periodontitis associated pregnancy complications. Ann Periodontol 1998;3:233-250.

10. Löe H. Periodontal changes in pregnancy. J Periodontol 1965;36:209-217.

11. Arafat AH. Periodontal status during pregnancy. J Periodontol 1974;45:641-643.

12. Hugoson A. Gingivitis in pregnant women. A longitudinal clinical study. Odontol Revy 1971;22:65-84.

13. Dasanayake AP. Poor periodontal health of the pregnant woman as a risk factor for low birth weight. Ann Periodontol 1998;3:206212.

14. Mitchell-Lewis D, Engebretson SP, Chen J, Lamster IB, Papapanou PN. Periodontal infections and preterm birth: early findings from a cohort of young minority women in New York. Eur J Oral Sci 2001;109:34-39.

15. López NJ, Smith PC, Gutierrez J. Higher risk of preterm birth and low birth weight in women with periodontal disease. J Dent Res 2002;81:58-63.

16. López NJ, Smith PC, Gutierrez J. Periodontal therapy may reduce the risk of preterm low birth weight in women with periodontal disease. J Periodontol 2002;73:911-924.

17. Jeffcoat MK, Hauth JC, Geurs NC, Reddy MS, Cliver SP, Hodgkins PM, Goldenberg RL. Periodontal disease and preterm birth: Results of a pilot intervention study. J Periodontol 2003;74:1214-1218.

18. Madianos PN, Lieff S, Murtha AP, Boggess KA, Auten RL Jr, Beck JD, Offenbacher S. Maternal periodontitis and prematurity. Part II: Maternal infection and fetal exposure. Ann Periodontol 2001;6:175-182

19. Geerts SO, Nys M, De MP, Charpentier J, Albert A, Legrand V, Rompen EH. Systemic release of endotoxins induced by gentle mastication: Association with periodontitis severity. J Periodontol 2002;73:73-78.

20. Ness PM, Perkins HA. Transient bacteremia after dental procedures and other minor manipulations. Transfusion 1980;20:82-85.

21. Boggess KA, Lieff S, Murtha AP, Moss K, Beck J, Offenbacher $\mathrm{S}$. Maternal periodontal disease is associated with an increased risk for pre-eclampsia. Obstet Gynecol 2003;101: 227-231.

22. Offenbacher S, Beck JD, Lieff S, Slade G. Role of periodontitis in systemic health: spontaneous preterm birth. J Dent Educ 1998;62:852-858.

23. Goldenberg RL, Hauth JC, Andrews WW. Intrauterine infection and preterm delivery. N Engl J Med 2000;342:1500-1507.
24. Yu VY. Developmental outcome of extremely preterm infants. Am J Perinatol 2000;17:57-61.

25. Saling E. Prevention of prematurity. A review of our activities during the last 25 years. J Perinat Med 1997;25:406-417.

26. Mozurkewich EL, Naglie G, Krahn MD, Hayashi RH. Predicting preterm birth: a cost-effectiveness analysis. Am J Obstet Gynecol 2000;182:1589-1598.

27. Tocharoen A, Thompson S, Addy C, Sargent R, Best R, Shoob $H$. Intergenerational and environmental factors influencing pregnancy outcomes. Ann Epidemiol 2000;10:475-476.

28. Kramer MS, Seguin L, Lydon J, Goulet L. Socioeconomic disparities in pregnancy outcome: why do the poor fare so poorly? Paediatr Perinat Epidemiol 2000;14:194-210.

29. Lawoyin TO. The relationship between maternal weight gain in pregnancy, hemoglobin level, stature, antenatal attendance and low birth weight. Southeast Asian J Trop Med Public Health 1997;28:873-876.

30. Nelson KB, Willoughby RE. Infection, inflammation and the risk of cerebral palsy. Curr Opin Neurol 2000;13:133-139.

31. Xiong X, Buekens P, Fraser WD, Beck J, Offenbacher S. Periodontal disease and adverse pregnancy outcomes: a systematic review. BJOG 2006;113:135-143.

32. Sadatmansouri S, Sedighpoor N, Aghaloo M. Effect of periodontal treatment phase I on birth term and birth weight. J Indian Soc Pedod Prev Dent 2006;24:23-26.

33. Tarannum F, Faizuddin M. Effect of periodontal therapy on pregnancy outcome in women affected by periodontitis. J Periodontol 2007;78:2095-2103.

34. Michalowicz BS, Hodges JS, DiAngelis AJ, Lupo VR, Novak MJ, Ferguson JE, et al. Treatment of periodontal disease and risk. N Engl J Med 2006;355:1885-1894.

35. Vergens JN, Sixou M, Preterm low birth weight and maternal periodontal status. A meta-analysis. Am J Obstet Gyncol 2007;196:135-e1-7.

36. Offenbacher S, Beck JD, Jared HL, Mauriello SM, Mendoza MC, Couper DJ, Stewart DD, Murtha, AP, Cochran DL, Dudley DJ, et al. Effects of periodontal therapy on rate of preterm delivery: a randomized controlled trial. Obstet Gynecol 2009;114:551-559.

37. Newnham JP, Newnham IA, Ball CM, Wright M, Pennell CE, Swain J, Doherty DA. Treatment of periodontal disease during pregnancy. Obstet Gynecol 2009;114:1239-1248.

38. Lopez JN, Da Silva I, Ipinza J, Gutierrez J. Periodontal therapy reduces the rate of preterm low birth weight in women with pregnancy-associated gingivitis. J Periodontol 2005;76: 2144-2153.

39. McManemy J, Cooke E, Amon E, Leet T. Recurrence risks of preterm delivery: Am J Obstet Gyncol 2007;196: 576 e1-6.

40. Polyzos NP, Polyzos IP, Mauri D, Tzioras S, Tsappi M, Cortinvous I, Cassaza G. Effect of periodontal disease treatment during pregnancy on preterm birth incidence: a meta-analysis of randomized trials. Am J Obstet Gyncol 2009;200:225-232.

\section{ABOUT THE AUTHOR}

\section{Adel S Alobaid}

Department of Restorative Dentistry, College of Dentistry King Khalid University, PO Box 3263 Zip 61471, Abha, Saudi Arabia, Phone: 00966172418014, Fax: 00966172418197 e-mail: aalobaid@kku.edu.sa 